\title{
Taxes, the tax administrative burden and the entrepreneurial life cycle
}

\author{
Pontus Braunerhjelm • Johan E. Eklund • Per Thulin
}

Accepted: 15 April 2019/Published online: 26 May 2019

(C) The Author(s) 2019

\begin{abstract}
We present a modified version of the entrepreneurial choice model, where it is shown that the expected utility of becoming an entrepreneur is decreasing in both the levels of taxes and the tax administrative burden. We extend previous empirical findings by examining how these variables influence entrepreneurs at different stages in the entrepreneurial life cycle. Our findings imply that the effect of the tax administrative burden varies over the entrepreneurial life cycle from strongly negative to insignificant. The most pronounced negative effects appear in the early stages of entrepreneurship. We conclude that a $10 \%$ reduction in the tax administrative burden increases the propensity for new business establishments by $4 \%$. Our findings support the idea that tax simplification is one way to encourage entrepreneurship, without any reduction in tax revenues.
\end{abstract}

Keywords Tax complexity - Tax administrative burden . Entrepreneurship · Life cycle

P. Braunerhjelm $(\bowtie)$

Swedish Entrepreneurship Forum, Blekinge Institute of Technology and KTH Royal Institute of Technology, SE-100 44 Stockholm, Sweden

e-mail: pontus.braunerhjelm@indek.kth.se

\section{J. E. Eklund}

Swedish Entrepreneurship Forum, Jönköping International Business School and Blekinge Institute of Technology, Stockholm, Sweden e-mail: johan.eklund@bth.se

P. Thulin

Swedish Entrepreneurship Forum, KTH Royal Institute of Technology, Stockholm, Sweden
JEL classification $\mathrm{L} 26 \cdot \mathrm{H} 25 \cdot \mathrm{K} 34 \cdot \mathrm{J} 24 \cdot \mathrm{M} 13$

\section{Introduction}

The economic effects of taxes on business activities have been studied extensively, including their impact on entrepreneurial endeavours. ${ }^{1}$ However, surprisingly, few studies have addressed how differences in the tax administrative burden and the associated compliance costs influence the frequency of start-ups and the propensity to engage in entrepreneurial ventures. ${ }^{2}$ This is even more astonishing given that small firm owners and entrepreneurs often express frustration with red tape linked to taxes. ${ }^{3}$ Based on data provided by the World Bank (2014a), their frustration appears well founded. A standard small firm in the USA is estimated to spend

\footnotetext{
${ }^{1}$ See Gordon (1998), Gentry and Hubbard (2000), Parker and Robson (2004), Cullen and Gordon (2007), Hanson (2008) and Henrekson and Sanandaji (2011) for overviews, arbitrage possibilities and how the structure of the tax system influences entrepreneurship. Regarding the relationship between taxes, wealth accumulation and entrepreneurship, see Evans and Jovanovic (1989), Banerjee and Newman (1993) and Hanson (2008).

${ }^{2}$ Stam and Verbeeten (2017) present a survey of the literature on tax compliances, emphasizing small firms and start-ups, but have no reference to its consequences for entry. Millán and Congregado (2012) conduct an analysis on survival of self-employed including a large host of micro- and macro-variables, including taxes. See also Belitski et al. (2016) and Da Rin et al. (2011) and the references therein. ${ }^{3}$ See e.g. World Bank (2010, 2015), The Economist (2014) and the Kauffman Foundation (2014). Chittenden et al. (2003), examining Australia, New Zealand, US and UK, claim that tax compliance costs constitute the major brunt of all compliance costs related to regulations that firms faces.
} 
approximately $175 \mathrm{~h}$ on reporting and paying taxes, whereas the corresponding figures for Germany, Sweden and Switzerland are 218, 122 and $63 \mathrm{~h}$, respectively. The economic effects of these regulatory differences have not been examined in a meaningful way, nor well understood.

The objective of this paper is to analyse how differences in the tax administrative burden influenced entrepreneurial behaviour in OECD countries during the period 2005-2012. By limiting the analysis to a group of developed rich countries, we are able to implicitly control for a number of unobserved country factors that might otherwise distort our results.

We argue that the effects are likely to be negative but will appear with different strength depending on which stage in the entrepreneurial life cycle that is considered. Based on data provided by the Global Entrepreneurship Monitor (GEM), the entrepreneurial life cycle can be classified into five different stages: it begins with the individual's intention to start a new firm, followed by the very early or nascent entrepreneurship stage ( $0-3$ months), which devolve into the so-called new business ownership (3-42 months) and established business ( $>42$ months) stages and finally exit. The last stage will not be considered in the empirical analysis because exit may occur at any of the stages.

Based on an occupational choice model extended to incorporate the costs of tax compliance, we conduct an empirical analysis showing that the tax administrative burden has a significant negative effect in most stages of the entrepreneur's life cycle; however, it is most pronounced for new businesses, i.e., firms that have begun to grow and generate revenue. Similarly, a significant and negative effect is reported for those intending to start a firm. Regarding nascent and established businesses, the effect is either less pronounced or attains a lower significance.

The negative and statistically significant results for entrepreneurial intention - as opposed to nascent firms, for which no such effect could be detected - could be interpreted as a type of self-selection effect or overoptimism. When the nascent firm moves to the next stage and generates revenue, the effect of high tax administrative costs becomes highly significant and negative. These findings are consistent with the view that the tax administrative burden shifts the expected utility of entrepreneurs towards seeking other employment opportunities. It is also consistent with the view that tax administration constitutes an entry barrier.

To our knowledge, only two studies have previously considered the relationship between tax administrative burden, compliance costs and entrepreneurial entry (Braunerhjelm and Eklund 2014, Djankov et al. 2010). In a study comprising 85 countries, Djankov et al. used tax compliance as a control variable, but it was not the focus of the analysis. Rather, they were interested in examining how effective corporate tax rates influenced investments and entrepreneurial entry. Their results indicated that a $10 \%$ increase in the corporate tax rate reduced entry rates by 2 to $5 \%$, whereas aggregate investments as a share of GDP declined by $2 \%$. Braunerhjelm and Eklund, using similar World Bank data, found a negative relationship between compliance costs and entry.

The present analysis offers new insight in several respects: first, we show that tax compliance constitutes an entry barrier for the conceivable pool of entrepreneurs, with potentially severe negative consequences for innovation and growth. ${ }^{4}$ Second, we are able to demonstrate the precise stage in the entrepreneurial life cycle where a high regulatory tax burden inflicts the most damage. Third, we pool individually based data (from the GEM database) with World Bank data and are not restricted to proxies for entrepreneurship, e.g. selfemployed or synthetic firms. Fourth, our analysis generates obvious policy implications, which are more profoundly anchored in empirical findings compared to previous analyses. Basically, a reduction of the tax administrative burden is likely to encourage more entrepreneurship, possibly without any reduction in tax revenues. Hence, complexity has a price.

The remainder of this paper is organized into four sections. In the following section, our theoretical framework is presented, including our hypotheses. Section 3 provides a description of the data we employ. In Section 4, we present our empirical findings, and Section 5 concludes.

\section{The choice to become an entrepreneur: a theoretical framework}

To make a living, most individuals choose between becoming an entrepreneur or becoming a wageearning employee. ${ }^{5}$ We implement an extended and

\footnotetext{
${ }^{4}$ There seems to be general agreement in the literature that there are interdependencies between entrepreneurship and innovation and that these variables are critically important for growth (Romer 1990, Aghion et al. 2013, Liang et al. 2014).

${ }^{5}$ For the sake of simplicity, we ignore the possibility that taxes and regulations may result in tax evasion and growth of the informal economy.
} 
slightly modified version of Lucas' (1978) occupational choice model. While heterogeneity in entrepreneurial ability affected the volume of production in the Lucas model, here it is assumed to affect the probability of success in entering an entrepreneurial venture. In addition, we let the profit function be affected by an information set, i.e. entrepreneurs at different phases in their endeavours might value a given entrepreneurial project differently.

Assume that individuals are homogenous in all respects except their entrepreneurial ability, which we assume follows a uniform distribution among the population according to,

$p \sim U(0,1)$

where we will identify $p$ as the probability of successful exploitation of a given entrepreneurial opportunity. Let $U$ denote the Von Neumann-Morgenstern utility function and $u$ a Bernoulli utility function, which we assume is strictly increasing in its argument. ${ }^{6}$ The utility of working as an employee $(L)$ can be expressed as:

$U(L)=u(w)$

where $w$ denotes the wage rate, which is known to the employee. By the same token, we can express the expected utility of becoming an entrepreneur as:

$U(E)=p u(\pi(1-\tau))+(1-p) u(0), \tau \in(0,1)$

where $\pi$ denotes profit before taxes if the entrepreneur is successful, $\tau$ represents the expected costs of a proportional corporate tax rate and $p$ denotes the idiosyncratic probability of entrepreneurial success. If the entrepreneur is unsuccessful, the expected utility is $u(0)$, which we set equal to zero. This implies that the expected utility of becoming an entrepreneur can be written as:

$U(E)=p u(\pi(1-\tau))$.

The individual is indifferent between the two occupational choices if the expected utility from working as an employee is equal to the expected utility from entrepreneurship,

$p^{*} u(\pi(1-\tau))=u(w)$.

\footnotetext{
${ }^{6}$ The Bernoulli utility function shows the utility attained for a given amount of wealth, while the Von Neumann-Morgenstern utility function provides the expected utility over a set of uncertain wealth outcomes.
}

Rearranging gives,

$p^{*}=\frac{u(w)}{u(\pi(1-\tau))}$.

The critical probability $p *$ thus divides the population into two distinct groups - those with a probability of succeeding as entrepreneurs less than $p^{*}$ and those with a probability of succeeding at least as large as $p^{*}$. The former group achieves higher expected utility from working as employees, while the latter group finds an entrepreneurial career more attractive. The share of entrepreneurs in the population thus depends on the relative utility of the wage and the after-tax profit that can be made by engaging in entrepreneurship.

Taking the total differential of Eq. (6) and holding wages constant yields,

$\frac{d p^{*}}{p^{*}}=\frac{u^{\prime}(\pi(1-\tau)) \pi}{u(\pi(1-\tau))} d \tau-\frac{u^{\prime}(\pi(1-\tau))(1-\tau)}{u(\pi(1-\tau))} d \pi$.

Thus, a higher corporate tax rate, $\tau$, or lower entrepreneurial profits for a successful entrepreneur, $\pi$, raise the critical probability $p^{*}$, and thus, fewer individuals choose entrepreneurship. This leads to our first hypothesis.

Hypothesis 1 Higher corporate taxes reduce the fraction of individuals who are entrepreneurs.

We model the profits from a successfully managed entrepreneurial activity as:

$\pi_{t}=f\left(x_{t}, c_{t}\right) \mid \Phi_{t}$

where $x$ is the production volume or output of the product or service that the entrepreneur is providing and $c$ represents the cost function. $\Phi_{t}$ denotes the information set available to the entrepreneur at time $t$ upon which expectations are formed. For our purposes, it is useful to think of the cost function as including the costs associated with the compliance of the tax code, i.e. the tax administrative burden. We argue that the tax system imposes a fixed cost as a result of the administrative burden associated with complying with the tax code (Crain and Hopkins 2001). ${ }^{7}$ This, in turn, implies that expected profits are reduced and the critical probability

\footnotetext{
${ }^{7}$ According to Crain and Hopkins, smaller firm encountered tax compliance costs per employee that were 1.8 times greater than in large service sector firms and 4.5 times greater than in large manufacturing industries.
} 
shifts in favour of becoming employed. This leads to our second hypothesis:

Hypothesis 2 A larger tax administrative burden will reduce the fraction of individuals who are entrepreneurs.

Tax complexity and the tax administrative burden may, in fact, have a more complicated impact on the cost function than one might suspect at first glance. To begin with, it is reasonable to expect that compliance with the tax code imposes both a fixed and a variable cost for the firm. The administrative cost can also be expected to increase both with the size of the firm and the complexity of the tax code. Larger firms may, for example, face more tax administration simply because they have a broader scope of activities, implying that they must comply with a larger number of rules. As firms grow, they may gradually encounter more tax rules and thus have to bear a larger tax administrative cost. For the same reason, a more complex tax code with a larger number of rules and loopholes is associated with higher compliance costs. A counteracting force is expected to be associated with learningby-doing effects, i.e. firms develop routines to handle taxes.

Thus, we expect not only that the tax administrative cost will shift the critical probability of becoming an entrepreneur but also that the effect may vary over the different stages that entrepreneurs go through. More precisely, if the information $\left(\Phi_{t}\right)$ an entrepreneur has on the tax administrative burden changes over the entrepreneurial stages - such as between the individual having entrepreneurial aspirations and entrepreneurs actually owning a new business establishment - the critical probability may shift.

To summarize, tax administrative burden is expected to deter entrepreneurship, but the strength of this effect depends on a range of factors that are likely to change as the firm proceeds through the different stages of the entrepreneurial life cycle.

Hypothesis 3 The effect of the tax administrative burden on the fraction of individuals who are entrepreneurs varies over firms' life cycles.

More precisely, we expect the negative effect of tax administrative burden to be lower for early stages of entrepreneurship due to the fact that the entrepreneur has yet not had experience in reporting and administrating taxes. Conversely, we expect the negative effect to diminish as the firm matures and the entrepreneur learns how to file taxes, i.e. learning effect.

\section{Data}

Data on entrepreneurship has been compiled from the Global Entrepreneurship Monitor (GEM), while data on tax rates and the tax administrative burden were provided by the World Bank Ease of Doing Business Indicators. ${ }^{8}$ From the GEM data, we employ five measures of entrepreneurial activity to capture the entrepreneurial life cycle. We are aware of alternative ways of classifying the firm over its life cycle (e.g. Churchill and Lewis 1983; Scott and Bruce 1987; Hanks et al. 1993), but only GEM provide data for an extensive number of countries. Moreover, the GEM classification is quite close to the previous suggestions, particularly Scott and Bruce's.

The first stage, entrepreneurial intention, measures the share of the population (age 18-64) who intend to start a business within the next 3 years. This basically captures how individuals evaluate the possibility of starting a firm compared to being an employee. The next stage in the entrepreneurial life cycle refers to new but not fully established businesses, denoted $n a$ scent entrepreneurship rate ( $0-3$ months). It measures the share of the population who are actively involved in setting up a business (own or co-own a business) but has not yet made any salary payments. The subsequent stage in the entrepreneurial life cycle is labelled new business ownership rate, which measures the share of the population who currently own a business and have made salary payments for more than 3 months but less than 42 months. Finally, we also use the share of the population who own a business - established business ownership rate-that has been active for more than 42 months. In addition, we implement an aggregate measure of entrepreneurship, total entrepreneurial activity (TEA), which captures the share of the population involved in nascent entrepreneurship or who are a new business owner (3-42 months).

From the World Bank Ease of Doing Business Indicators, we collect data that measure the taxes on profits,

\footnotetext{
${ }^{8}$ See GEM (2015) and World Bank (2014a) for more details and the methodology behind that data.
} 
the tax administrative burden and the entry costs. To construct a measure of the tax administrative burden, we conduct a principal component analysis of the time it takes to pay taxes and the cost to pay taxes. Taxes are measured as the share of corporate profits, and we also utilize corporate taxes divided by the average income tax rate as an alternative specification. In addition, we control for entry barriers, defined as the cost of starting a business as a share of per capita income. ${ }^{9}$

We expect the tax variables and the cost of starting a business to have a negative impact on entrepreneurship (Ardagna and Lusardi 2009). As controls, we also include the growth rate of GDP per capita lagged 1 year and the average annual real wage income (collected from the World Development Indicators, World Bank (2014) and OECD Statistics, respectively). ${ }^{10}$ Higher average wages raise individuals' utility from working as employees relative to that of being entrepreneurs. This in turn will switch the optimal career choice of the marginal entrepreneur from entrepreneurship towards salaried employment. In addition, higher wages also make it costlier for an entrepreneur to hire workers. Both of these effects should deter entrepreneurship and, consequently, we expect that an increase in average wages, ceteris paribus, will decrease the fraction of individuals engaged in entrepreneurship. All variables with the exception of the growth rate are in natural logarithms. See Table 1 for further details and descriptive statistics. After merging the variables, we have an unbalanced panel covering 29 OECD countries (161 observations).

\section{Empirical strategy and results}

The correlations between the variables implemented in the empirical analysis are reported in Table 2. It is worth noting that the correlation between the different stages in the entrepreneurial life cycle is relatively low, indicating that they do in fact capture different aspects of entrepreneurship. The correlation between entrepreneurial intention and new business ownership is 0.19 , and

\footnotetext{
${ }^{9}$ Almost 30 years ago, Brock and Evans (1986) presented findings that the costs of complying with regulation were approximately ten times higher for small firms.

${ }^{10}$ See Koellinger and Thurik (2012) regarding the relationship between the business cycle and entrepreneurship.
}

the correlation between entrepreneurial intention and established businesses is close to zero. ${ }^{11}$

Next, we estimate the following model:

$\ln$ Entrp $_{i, t}=\beta_{0}$ Taxburden $_{i, t}+\mathbf{X}_{i, t}^{\prime} \boldsymbol{\beta}+\eta_{i}+\varepsilon_{i, t}$

where we use the five measures related to the different stages in the entrepreneurial life cycle as our dependent variables. Our key explanatory variable is the tax administrative burden (Taxburden), and we include the control variables described in Section 3 in vector $\mathbf{X}$. Sub index $i$ and $t$ denote country and time, respectively. Access to panel data allows us to use a country fixed-effects model (captured by $\eta_{i}$ ), which will remove unobserved country heterogeneity. In each regression, we exclude one to four observations on the basis that they are considered extreme outliers (defined as having a residual larger than three standard deviations in absolute value). ${ }^{12}$

The results are presented in Table 3 below. ${ }^{13}$ We find that the tax administrative burden has a negative effect on all stages of entrepreneurship, with the exception of nascent entrepreneurship activity, which fails to achieve statistical significance. The negative effect appears to be strongest for new business ownership rates and is approximately similar in size for entrepreneurial intention and the established business ownership rate. This may appear puzzling at first sight. Our interpretation, however, is that nascent entrepreneurship should, in fact, be an entrepreneurial stage that is less affected by tax considerations.

The reason for this is straightforward. In the planning stage, where individuals have the intention to start a business before actually reaching such a stage, the potential entrepreneur takes tax administration costs into consideration. Once the individual has decided to embark on entrepreneurship, there is a self-selection effect at work whereby the individual has made a subjective evaluation of the costs and benefits of starting a firm, including the tax administration costs. However, in the next step of the entrepreneurial life cycle (new business ownership), entrepreneurs start to generate revenue and tax administration costs materialize. This is the first stage of business activity where business owners actually become involved in tax compliance. The new

\footnotetext{
${ }^{11}$ For a discussion of different entrepreneurship measures, see Acs et al. (2008).

${ }^{12}$ Depending on the entrepreneurship stage, extreme values are found for Austria in 2007 and 2012, Belgium in 2007 and 2011, Hungary in 2005 and 2011, Japan in 2005 and Mexico in 2008 and 2010.

${ }^{13}$ The pooled OLS results for the tax administrative burden, reported in Table 5 in the Appendix, are similar to the fixed effects results.
} 
Table 1 Variable description and summary statistics

\begin{tabular}{|c|c|c|c|c|c|c|}
\hline Variable & Description & Source & Mean & $\begin{array}{l}\text { Std. } \\
\text { dev. }\end{array}$ & Min & Max \\
\hline $\begin{array}{l}\text { Entrepreneurial } \\
\text { intention }\end{array}$ & $\begin{array}{l}\text { Percentage of } 18-64 \text { population (individuals in- } \\
\text { volved in any stage of entrepreneurial activity } \\
\text { excluded) who intend to start a business within } \\
3 \text { years }\end{array}$ & $\begin{array}{l}\text { Global Entrepreneurship } \\
\text { Monitor }\end{array}$ & 9.0 & 4.6 & 0.8 & 25.6 \\
\hline TEA & $\begin{array}{l}\text { Percentage of } 18-64 \text { population who are either a } \\
\text { nascent entrepreneur or owner-manager of a } \\
\text { new business }\end{array}$ & $\begin{array}{l}\text { Global Entrepreneurship } \\
\text { Monitor }\end{array}$ & 6.5 & 2.4 & 1.9 & 14.3 \\
\hline $\begin{array}{l}\text { Nascent } \\
\text { entrepreneurship } \\
\text { rate }\end{array}$ & $\begin{array}{l}\text { Percentage of } 18-64 \text { population who are currently } \\
\text { a nascent entrepreneur, i.e. actively involved in } \\
\text { setting up a business they will own or co-own; } \\
\text { this business has not paid salaries, wages, or any } \\
\text { other payments to the owners for more than } \\
\text { three months }\end{array}$ & $\begin{array}{l}\text { Global Entrepreneurship } \\
\text { Monitor }\end{array}$ & 3.8 & 1.7 & 1.1 & 9.5 \\
\hline $\begin{array}{l}\text { New business } \\
\text { ownership rate }\end{array}$ & $\begin{array}{l}\text { Percentage of } 18-64 \text { population who are currently } \\
\text { an owner-manager of a new business, i.e. } \\
\text { owning and managing a running business that } \\
\text { has paid salaries, wages, or any other payments } \\
\text { to the owners for more than } 3 \text { months, but not } \\
\text { more than } 42 \text { months }\end{array}$ & $\begin{array}{l}\text { Global Entrepreneurship } \\
\text { Monitor }\end{array}$ & 2.8 & 1.2 & 0.4 & 6.5 \\
\hline $\begin{array}{l}\text { Established } \\
\text { business } \\
\text { ownership rate }\end{array}$ & $\begin{array}{l}\text { Percentage of } 18-64 \text { population who are currently } \\
\text { owner-manager of an established business, i.e. } \\
\text { owning and managing a running business that } \\
\text { has paid salaries, wages, or any other payments } \\
\text { to the owners for more than } 42 \text { months }\end{array}$ & $\begin{array}{l}\text { Global Entrepreneurship } \\
\text { Monitor }\end{array}$ & 6.5 & 2.8 & 0.4 & 15.8 \\
\hline $\begin{array}{l}\text { Tax administrative } \\
\text { burden }\end{array}$ & $\begin{array}{l}\text { A proxy for the tax administrative burden, obtained } \\
\text { through factor analysis (principal component) of } \\
\text { the number of tax payments per year and the } \\
\text { time to pay taxes in hours per year }\end{array}$ & $\begin{array}{l}\text { Own calculation based on } \\
\text { data from The World } \\
\text { Bank, Doing Business }\end{array}$ & 1.4 & 1.4 & 0.1 & 8.2 \\
\hline Corporate tax rate & Total corporate tax rate as a percentage of profits & $\begin{array}{l}\text { The World Bank, Doing } \\
\text { Business }\end{array}$ & 47.5 & 11.5 & 26.3 & 77.5 \\
\hline $\begin{array}{l}\text { Relative corporate } \\
\text { tax rate }\end{array}$ & $\begin{array}{l}\text { Corporate tax rate divided by the average income } \\
\text { tax rate, } 100 \% \text { of average earnings }\end{array}$ & $\begin{array}{l}\text { Own calculation based on } \\
\text { data from The World Bank } \\
\text { and OECD }\end{array}$ & 3.7 & 2.3 & 0.8 & 17.9 \\
\hline Entry cost & $\begin{array}{l}\text { Cost of starting a business as a percentage of the } \\
\text { share of income per capita }\end{array}$ & $\begin{array}{l}\text { The World Bank, Doing } \\
\text { Business }\end{array}$ & 6.6 & 6.6 & 0.1 & 22.5 \\
\hline Growth & $\begin{array}{l}\text { Annual growth rate of real PPP-adjusted GDP per } \\
\text { capita US\$, lagged } 1 \text { year }\end{array}$ & $\begin{array}{l}\text { Own calculation based on } \\
\text { data from The World } \\
\text { Bank, World Development } \\
\text { Indicators }\end{array}$ & 1.2 & 2.9 & -9.0 & 8.3 \\
\hline Annual wage & $\begin{array}{l}\text { Annual average wage; } 2013 \text { US\$ PPPs and } 2013 \\
\text { constant prices }\end{array}$ & OECD & 38,106 & 10,317 & 12,329 & 56,067 \\
\hline
\end{tabular}

All entries based on 161 observations from 29 countries

information is likely to spark a reassessment of such expenditures.

As businesses become established (older than 42 months) and regularly make payments, the tax administrative burden becomes less important, which may be explained by learning-by-doing effects and fixed costs. Hence, it is important to recognize that the expected profit and, in particular, the expected costs are not constant over the entrepreneurial life cycle.

Note that including the tax administrative burden implies that neither the tax rate nor our broad measure of entry costs/barriers has any significant effect on entrepreneurship with the exception of entrepreneurial intention, where corporate taxes have a negative and significant effect. This can in part be explained by the country fixed effects removing the unobserved heterogeneity, which is presumably correlated with the cost of entry. For example, the pooled OLS results presented in Table 5 in the Appendix demonstrate that both the total tax rate and the cost of starting a business are much more significant when the country fixed effects are neglected. Another interesting result from Table 5 is that the share 
Table 2 Correlation matrix

\begin{tabular}{|c|c|c|c|c|c|c|c|c|c|c|c|}
\hline & (1) & (2) & (3) & (4) & $(5)$ & (6) & (7) & (8) & (9) & $(10)$ & (11) \\
\hline (1) Entrepreneurial intention & 1 & & & & & & & & & & \\
\hline (2) TEA & 0.46 & 1 & & & & & & & & & \\
\hline (3) Nascent entrepreneurship rate & 0.52 & 0.90 & 1 & & & & & & & & \\
\hline (4) New business ownership rate & 0.19 & 0.80 & 0.47 & 1 & & & & & & & \\
\hline (5) Established business ownership rate & -0.08 & 0.36 & 0.11 & 0.58 & 1 & & & & & & \\
\hline (6) Tax administrative burden & 0.30 & -0.01 & 0.12 & -0.21 & -0.21 & 1 & & & & & \\
\hline (7) Corporate tax rate & 0.09 & -0.24 & -0.06 & -0.40 & -0.38 & 0.14 & 1 & & & & \\
\hline (8) Relative corporate tax rate & 0.45 & 0.07 & 0.14 & -0.08 & -0.05 & 0.65 & 0.18 & 1 & & & \\
\hline (9) Entry cost & 0.15 & -0.13 & -0.16 & -0.06 & 0.20 & 0.38 & 0.33 & 0.46 & 1 & & \\
\hline (10) Growth & 0.11 & 0.15 & 0.15 & 0.11 & -0.07 & 0.22 & -0.02 & 0.03 & -0.01 & 1 & \\
\hline (11) Annual wage & -0.51 & -0.04 & -0.11 & 0.10 & 0.14 & -0.60 & -0.26 & -0.58 & -0.52 & -0.13 & 1 \\
\hline
\end{tabular}

Entries in italics refer to statistical significance at the 5-percentage level. Please note that TEA is a summary measure of both nascent entrepreneurship and new business ownership and it is therefore by construction highly correlated to both these variables

of established business ownership is positively and highly significantly related to the cost of starting a business - a result that is consistent with the interpretation that higher obstacles to entry reduce competition and are, therefore, beneficial for firms that are already established in the market.

Table 4 reports the results using the corporate tax rate divided by the average income tax rate for a person with average earnings as an alternative specification of the overall tax pressure. ${ }^{14}$ The results are very similar to those reported in Table 3-the tax variable is insignificant in all stages of the entrepreneurial life cycle, while the tax burden remains negative and significant in all regressions with the exception of nascent entrepreneurship, where it is insignificant.

We perform a number of robustness checks on our results. Some of the findings are presented in Tables 5, 6, $7,8,9,10,11$ and 12 in the Appendix. One robustness check we perform is to omit our measure of the tax administrative burden to determine whether it has any influence on the effect of the tax rate. We find few effects of this with the exception of established businesses, for which the tax rate becomes significantly negative. Moreover, judging from the estimates in Tables 8, 9, 10, 11 and 12, excluding tax burdens tend to cause us to overestimate the effect of corporate taxes on entrepreneurship. For example, observing the last two columns of Table 8 , the elasticity of

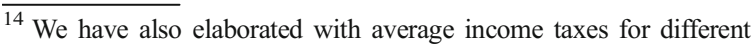
percentiles in the income distribution to see how this might affect entrepreneurship. The results presented in Tables 6 and 7 in the Appendix are very similar to those in Table 4.
}

entrepreneurial intention with respect to the corporate tax rate is overestimated by 0.33 percentage points (1.4091.075) if we do not control for the tax administrative burden.

In addition to the robustness tests mentioned above, we also began with a regression specification including only the tax administrative burden and then added one additional variable at a time (see Tables 8, 9, 10, 11 and 12 in the Appendix). The estimated coefficient for the tax administrative burden is shown to be remarkably stable throughout the different specifications. Finally, we have also experimented with variables capturing industry shares for both newly formed firms as well as for more established firms as additional controls. The new control variables received almost no support in our regressions and the results for the other variables remained virtually unchanged. ${ }^{15}$

\section{Conclusions}

Economists have long analysed the effects of taxes on economic activities and their influence on the allocation of resources. However, very little attention has been given to the effects of the costs of complying with taxes. Modern tax codes are often complex, and compliance requires both time and resources. However, there is also a significant cross-country variation in the complexity of tax systems. A standard small firm in the USA is, for example estimated to spend approximately $175 \mathrm{~h}$ on reporting and paying taxes, whereas the corresponding figures for Germany, Sweden and Switzerland are 218, 122 and 63 h, respectively. We

\footnotetext{
${ }^{15}$ The results are available from the authors upon request.
} 
Table 3 Entrepreneurship and tax administrative burden - panel regressions with fixed country effects

\begin{tabular}{llllll}
\hline & $\begin{array}{l}\text { (1) Ln } \\
\text { entrepreneurial } \\
\text { intention }\end{array}$ & (2) Ln TEA & $\begin{array}{l}\text { (3) Ln nascent } \\
\text { entrepreneurship rate }\end{array}$ & $\begin{array}{l}\text { (4) Ln new business } \\
\text { ownership rate }\end{array}$ & $\begin{array}{l}\text { (5) Ln establish business } \\
\text { ownership rate }\end{array}$ \\
\hline $\begin{array}{l}\text { Ln tax administrative } \\
\text { burden }\end{array}$ & $-0.124^{* * *}(-3.06)$ & $-0.133^{* * *(-2.83)}$ & $-0.023(-0.59)$ & $-0.391^{* * *(-3.35)}$ & $-0.139^{*}(-1.86)$ \\
Ln corporate tax rate & $-1.075^{* * *}(-2.40)$ & $0.094(0.37)$ & $-0.054(-0.20)$ & $0.691(1.68)$ & $-0.281(-1.06)$ \\
Ln entry cost & $0.012(0.29)$ & $-0.055(-1.43)$ & $-0.074(-1.40)$ & $-0.040(-0.80)$ & $0.008(0.27)$ \\
Ln annual wage & $-0.070(-0.09)$ & $-0.751(-1.31)$ & $-0.641(-0.80)$ & $-1.087^{*}(-1.94)$ & $-0.167(-0.43)$ \\
Growth & $0.016^{* *(2.12)}$ & $0.019^{* * *(3.34)}$ & $0.024^{* *}(2.62)$ & $0.016^{*}(1.72)$ & $-0.0003(-0.08)$ \\
Constant & $6.888(0.81)$ & $9.379(1.62)$ & $8.270(0.98)$ & $9.711(1.63)$ & $4.606(1.07)$ \\
$R^{2}$ & 0.16 & 0.12 & 0.08 & 0.24 & 0.08 \\
No. of countries & 29 & 29 & 29 & 29 & 29 \\
No. of observations & 159 & 158 & 160 & 157 & 157 \\
\hline
\end{tabular}

$t$ statistics based on robust standard errors in parentheses. Asterisks $(*),(* *)$ and $(* * *)$ denote statistical significance at the 10-, 5- and 1percentage levels, respectively. The maximum number of observations available for estimation is 161 , but a few observations have been deleted because they are considered extreme outliers (|residual $\mid>3$ standard deviations)

argue that tax compliance imposes a significant administrative burden that negatively influences entrepreneurial intentions and activities, with potentially far-reaching effects on the number of individuals willing to become entrepreneurs. Such costs could also have a signalling effect, where less benevolent attitudes are associated with larger administrative tax burdens.

Based on a simple occupational choice model, we have argued that the administrative tax burden primarily influences the early stages of entrepreneurship. When firms become more mature, the costs associated with the tax administrative burden diminish due to learning, i.e. entrepreneurs and firms develop routines to handle taxes. Because costs related to the administration of taxes can largely be regarded as a fixed cost, their negative effects would be particularly prevalent for young and small firms.

Our findings provide empirical support for these hypotheses. We use data on taxes, the tax administrative burden and entry barriers from the World Bank Ease of Doing Business Indicators. We measure the tax administrative burden as a combination of the time to pay taxes and number of tax payments a year, derived for a standard firm through principal component analysis. The

Table 4 Entrepreneurship and tax administrative burden - panel regressions with fixed country effects. Corporate tax rate divided by average income tax, $100 \%$ of average earnings

\begin{tabular}{|c|c|c|c|c|c|}
\hline & $\begin{array}{l}\text { (1) } \mathrm{Ln} \\
\text { entrepreneurial } \\
\text { intention }\end{array}$ & (2) Ln TEA & $\begin{array}{l}\text { (3) Ln nascent } \\
\text { entrepreneurship } \\
\text { rate }\end{array}$ & $\begin{array}{l}\text { (4) Ln new } \\
\text { business } \\
\text { ownership rate }\end{array}$ & $\begin{array}{l}\text { (5) Ln establish } \\
\text { business } \\
\text { ownership rate }\end{array}$ \\
\hline $\begin{array}{l}\text { Ln tax administrative } \\
\text { burden }\end{array}$ & $-0.170 * * *(-3.32)$ & $\begin{array}{c}-0.132 * * * \\
(-2.82)\end{array}$ & $-0.016(-0.34)$ & $\begin{array}{c}-0.367 * * * \\
(-2.67)\end{array}$ & $-0.140 *(-1.77)$ \\
\hline $\begin{array}{l}\text { Ln relative corporate tax } \\
\text { rate }\end{array}$ & $-0.126(-0.41)$ & $0.031(0.18)$ & $-0.069(-0.31)$ & $0.131(0.44)$ & $-0.052(-0.35)$ \\
\hline Ln entry cost & $-0.024(-0.43)$ & $-0.052(-1.52)$ & $-0.074(-1.41)$ & $-0.022(-0.47)$ & $0.013(0.39)$ \\
\hline Ln average annual wage & $0.025(0.03)$ & $-0.755(-1.31)$ & $-0.648(-0.80)$ & $-1.119 * *(-2.13)$ & $0.008(0.02)$ \\
\hline Growth & $0.013(1.64)$ & $0.019 * * *(3.20)$ & $0.024 * *(2.55)$ & $0.019 *(1.91)$ & $-0.002(-0.58)$ \\
\hline Constant & $1.972(0.25)$ & $9.745(1.60)$ & $8.214(0.96)$ & $12.52 * *(2.31)$ & $1.736(0.44)$ \\
\hline$R^{2}$ & 0.11 & 0.12 & 0.08 & 0.22 & 0.06 \\
\hline No. of countries & 29 & 29 & 29 & 29 & 29 \\
\hline No. of observations & 159 & 158 & 160 & 158 & 158 \\
\hline
\end{tabular}

$t$ statistics based on robust standard errors in parentheses. Asterisk $(*),(* *)$ and $(* * *)$ denote statistical significance at the 10-, 5- and 1percentage levels, respectively. The maximum number of observations available for estimation is 161 , but a few observations have been deleted because they are extreme outliers (|residual $\mid>3$ standard deviations) 
analysis is limited to the rich OECD group of countries, which should be kept in mind when comparing our results to, e.g. Djankov et al. (2010) and Braunerhjelm and Eklund (2014). The results reveal strong support for the negative effect of a higher tax administrative burden on both entrepreneurial intention and total entrepreneurial activity.

We conclude that the impact differs in magnitude between different entrepreneurial stages. For our broad measure of total entrepreneurial activity (TEA), we find that a reduction in the tax administrative burden of $10 \%$ would increase total entrepreneurial activity by approximately $1.3 \%$. For entrepreneurs that have survived the first 3 months (new business ownership rate), the corresponding figure is $3.9 \%$. However, we find no significant negative effects on the very early stages of business start-ups (nascent entrepreneurship), where the entrepreneur has made no payments, and only a weak significant effect can be observed for established businesses. These findings are in line with the view that the impact of tax administration costs varies over the entrepreneurial life cycle. Moreover, the tax administrative burden has no impact on more established businesses which is consistent with learningby-doing and scale effects; entrepreneurs learn how to cope with tax administration, and established firms can more easily cope with fixed costs associated with tax compliance.

Our policy conclusions are straightforward. Tax complexity has a price and reducing the tax administrative burden is shown to encourage entrepreneurship, possibly without reducing tax revenues. Examining the extent to which a lower tax administrative burden co-varies with tax revenue and the potential costs inflicted on society due to a lower innovation rate are, however, tasks for future research. Similarly, how to optimize compliance costs associated with taxes over a firm's life cycle, taking into account that different stages may require different legal forms as well as different competencies, constitutes another conceivable future research avenue.

Simplicity and transparency certainly qualify as important features of any tax system, yet these aspects seem to carry particular importance for the entrepreneurial endeavour at certain stages. That refers to the optimal taxation theory and may motivate simple lump-sum tax rules in the early stages of firms' life cycle in order to allow higher tax revenues as firms become more mature. Finally, tax compliance at the firm level is likely to be influenced by a number of factors such as the performance of the firm and the tax 'culture'. Future research should thus attempt to include individual as well as firmlevel variables into the analysis.

Acknowledgments We are grateful for comments and valuable suggestions given by participants at the Druid conference 2017 in New York and the Indiana University/Henley Business School workshop in Berlin.

Funding information The authors are grateful to the financial support from the Marianne and Marcus Wallenberg Foundation.

\section{Appendix Robustness check}

Table 5 Entrepreneurship and tax administrative burden-OLS regressions

\begin{tabular}{|c|c|c|c|c|c|}
\hline & $\begin{array}{l}\text { (1) } \mathrm{Ln} \\
\text { entrepreneurial } \\
\text { intention }\end{array}$ & (2) Ln TEA & $\begin{array}{l}\text { (3) Ln nascent } \\
\text { entrepreneurship rate }\end{array}$ & $\begin{array}{l}\text { (4) Ln new business } \\
\text { ownership rate }\end{array}$ & $\begin{array}{l}\text { (5) Ln establish business } \\
\text { ownership rate }\end{array}$ \\
\hline $\begin{array}{l}\text { Ln tax administrative } \\
\text { burden }\end{array}$ & $-0.092 * *(-2.17)$ & $-0.078 * *(-2.02)$ & $-0.024(-0.51)$ & $-0.145 * * *(-3.55)$ & $-0.093 * *(-1.98)$ \\
\hline Ln corporate tax rate & $-0.054(-0.39)$ & $-0.408 * * *(-4.55)$ & $-0.107(-1.00)$ & $-0.773 * * *(-5.90)$ & $-0.774 * * *(-5.46)$ \\
\hline Ln entry cost & $-0.048(-1.46)$ & $-0.038(-1.50)$ & $-0.109 * * *(-3.69)$ & $0.049(1.46)$ & $0.133 * * *(3.70)$ \\
\hline Ln average annual wage & $-0.998 * * *(-10.39)$ & $-0.423 * * *(-3.60)$ & $-0.507 * * *(-3.58)$ & $-0.155(-1.06)$ & $0.217(1.49)$ \\
\hline Growth & $0.015(1.48)$ & $0.018 * *(2.20)$ & $0.021^{*}(1.87)$ & $0.015(1.46)$ & $-0.004(-0.31)$ \\
\hline Constant & $12.81 * * *(10.68)$ & $7.845^{* * *}(5.86)$ & 7.108*** (4.47) & $5.439 * * *(3.22)$ & $2.308(1.35)$ \\
\hline$R^{2}$ & 0.30 & 0.20 & 0.19 & 0.24 & 0.25 \\
\hline No. of countries & 29 & 29 & 29 & 29 & 29 \\
\hline No. of observations & 159 & 160 & 160 & 160 & 159 \\
\hline
\end{tabular}

$t$ statistics based on robust standard errors in parentheses. Asterisks $(*),(* *)$ and $(* * *)$ denote statistical significance at the 10-, 5- and 1percentage levels, respectively. The maximum number of observations available for estimation is 161 , but a few observations have been deleted because they are extreme outliers (|residual $\mid>3$ standard deviations) 
Table 6 Entrepreneurship and tax administrative burden - panel regressions with fixed country effects. Corporate tax rate divided by average income tax, $67 \%$ of average earnings

\begin{tabular}{|c|c|c|c|c|c|}
\hline & $\begin{array}{l}\text { (1) } \mathrm{Ln} \\
\text { entrepreneurial } \\
\text { intention }\end{array}$ & (2) Ln TEA & $\begin{array}{l}\text { (3) Ln nascent } \\
\text { entrepreneurship } \\
\text { rate }\end{array}$ & $\begin{array}{l}\text { (4) Ln new } \\
\text { business } \\
\text { ownership rate }\end{array}$ & $\begin{array}{l}\text { (5) Ln establish } \\
\text { business } \\
\text { ownership rate }\end{array}$ \\
\hline $\begin{array}{l}\text { Ln tax administrative } \\
\text { burden }\end{array}$ & $-0.207 * * *(-4.87)$ & $\begin{array}{r}-0.121 * * \\
(-2.12)\end{array}$ & $0.031(0.78)$ & $-0.374 * *(-2.51)$ & $-0.155^{*}(-1.81)$ \\
\hline $\begin{array}{l}\text { Ln relative corporate tax } \\
\text { rate }\end{array}$ & $-0.048(-0.27)$ & $-0.032(-0.36)$ & $-0.203 * *(-2.29)$ & $0.121(0.96)$ & $-0.022(-0.31)$ \\
\hline Ln entry cost & $-0.024(-0.45)$ & $-0.045(-1.33)$ & $-0.056(-1.19)$ & $-0.024(-0.49)$ & $-0.002(-0.05)$ \\
\hline $\begin{array}{l}\text { Ln average annual } \\
\text { wage }\end{array}$ & $0.004(0.00)$ & $-0.583(-0.92)$ & $0.108(0.13)$ & $-1.592 * *(-2.74)$ & $-0.183(-0.47)$ \\
\hline Growth & $0.015^{*}(1.92)$ & $0.022 * * *(3.37)$ & $0.032 * * *(3.54)$ & $0.011(1.45)$ & $-0.0002(-0.05)$ \\
\hline Constant & $2.071(0.23)$ & $8.013(1.21)$ & $0.471(0.05)$ & $17.50 * * *(2.93)$ & $3.763(0.92)$ \\
\hline$R^{2}$ & 0.11 & 0.12 & 0.14 & 0.20 & 0.08 \\
\hline No. of countries & 28 & 28 & 28 & 28 & 28 \\
\hline No. of observations & 154 & 153 & 154 & 153 & 152 \\
\hline
\end{tabular}

$t$ statistics based on robust standard errors in parentheses. Asterisk $(*),(* *)$ and $(* * *)$ denote statistical significance at the 10-, 5- and 1percentage levels, respectively. The maximum number of observations available for estimation is 156 , but a few observations have been deleted because they are extreme outliers (|residual $\mid>3$ standard deviations)

Table 7 Entrepreneurship and tax administrative burden - panel regressions with fixed country effects. Corporate tax rate divided by average income tax, $167 \%$ of average earnings

\begin{tabular}{|c|c|c|c|c|c|}
\hline & $\begin{array}{l}\text { (1) } \mathrm{Ln} \\
\text { entrepreneurial } \\
\text { intention }\end{array}$ & (2) Ln TEA & $\begin{array}{l}\text { (3) Ln nascent } \\
\text { entrepreneurship } \\
\text { rate }\end{array}$ & $\begin{array}{l}\text { (4) Ln new } \\
\text { business } \\
\text { ownership rate }\end{array}$ & $\begin{array}{l}\text { (5) Ln establish business } \\
\text { ownership rate }\end{array}$ \\
\hline $\begin{array}{l}\text { Ln tax administrative } \\
\text { burden }\end{array}$ & $-0.168 * * *(-3.98)$ & $\begin{array}{c}-0.133 * * * \\
(-3.06)\end{array}$ & $-0.022(-0.58)$ & $\begin{array}{c}-0.365 * * * \\
(-3.10)\end{array}$ & $-0.138 *(-1.97)$ \\
\hline $\begin{array}{l}\text { Ln relative corporate tax } \\
\text { rate }\end{array}$ & $-0.333(-0.66)$ & $0.093(0.42)$ & $-0.080(-0.28)$ & $0.309(0.81)$ & $-0.165(-0.78)$ \\
\hline Ln entry cost & $-0.019(-0.37)$ & $-0.054(-1.55)$ & $-0.074(-1.42)$ & $-0.022(-0.47)$ & $0.016(0.45)$ \\
\hline Ln average annual wage & $-0.080(-0.10)$ & $-0.727(-1.28)$ & $-0.665(-0.81)$ & $\begin{aligned}-1.034 * \\
(-2.01)\end{aligned}$ & $-0.047(-0.13)$ \\
\hline Growth & $0.014 *(1.75)$ & $0.019 * * *(3.25)$ & $0.024 * *(2.54)$ & $0.017 *(1.84)$ & $-0.002(-0.50)$ \\
\hline Constant & $3.174(0.39)$ & $9.414(1.58)$ & $8.379(0.97)$ & $11.55 * *(2.16)$ & $2.382(0.59)$ \\
\hline$R^{2}$ & 0.12 & 0.12 & 0.08 & 0.23 & 0.06 \\
\hline No. of countries & 29 & 29 & 29 & 29 & 29 \\
\hline No. of observations & 159 & 158 & 160 & 157 & 158 \\
\hline
\end{tabular}

$t$ statistics based on robust standard errors in parentheses. Asterisks $(*),(* *)$ and $(* * *)$ denote statistical significance at the 10-, 5- and 1percentage levels, respectively. The maximum number of observations available for estimation is 161 , but a few observations have been deleted because they are extreme outliers ( $\mid$ residual $\mid>3$ standard deviations) 
Table 8 Entrepreneurial intention and tax administrative burden - panel regressions with fixed country effects, alternative specifications

\begin{tabular}{|c|c|c|c|c|c|c|}
\hline & (1) & (2) & (3) & (4) & (5) & (6) \\
\hline $\begin{array}{l}\text { Ln tax administrative } \\
\text { burden }\end{array}$ & $\begin{array}{c}-0.165 * * * \\
(-3.48)\end{array}$ & $\begin{array}{r}-0.099 * * \\
(-2.28)\end{array}$ & $\begin{array}{r}-0.098 * * \\
(-2.24)\end{array}$ & $\begin{array}{r}-0.098 * * \\
(-2.19)\end{array}$ & $\begin{array}{c}-0.124 * * * \\
(-3.06)\end{array}$ & - \\
\hline Ln corporate tax rate & - & $\begin{array}{c}-0.935^{*} \\
(-1.95)\end{array}$ & $\begin{array}{l}-0.969^{*} \\
(-1.93)\end{array}$ & $\begin{array}{l}-0.974^{*} \\
(-1.89)\end{array}$ & $\begin{array}{r}-1.075 * * \\
(-2.40)\end{array}$ & $\begin{array}{c}-1.409 * * * \\
(-4.41)\end{array}$ \\
\hline Ln entry cost & - & - & $0.012(0.32)$ & $0.010(0.26)$ & $0.012(0.29)$ & $0.016(0.37)$ \\
\hline $\begin{array}{l}\text { Ln average annual } \\
\text { wage }\end{array}$ & - & - & - & $-0.119(-0.13)$ & $-0.070(-0.09)$ & $-0.072(-0.09)$ \\
\hline Growth & - & - & - & - & $0.016^{* *}(2.12)$ & $0.013 *(1.77)$ \\
\hline Constant & $2.068 * * *(365)$ & $5.654 * * *(3.08)$ & $5.771 * * *(3.02)$ & $7.041(0.70)$ & $6.888(0.81)$ & $8.203(0.95)$ \\
\hline$R^{2}$ & 0.08 & 0.13 & 0.13 & 0.13 & 0.16 & 0.13 \\
\hline No. of countries & 29 & 29 & 29 & 29 & 29 & 29 \\
\hline No. of observations & 159 & 159 & 159 & 159 & 159 & 159 \\
\hline
\end{tabular}

$t$ statistics based on robust standard errors in parentheses. Asterisks $(*),(* *)$ and $(* * *)$ denote statistical significance at the 10-, 5- and 1percentage levels, respectively. The maximum number of observations available for estimation is 161 , but a few observations have been deleted because they are extreme outliers ( $\mid$ residual $\mid>3$ standard deviations)

Table 9 Total entrepreneurial activity (TEA) and tax administrative burden - panel regressions with fixed country effects, alternative specifications

\begin{tabular}{|c|c|c|c|c|c|c|}
\hline & (1) & (2) & (3) & (4) & (5) & (6) \\
\hline $\begin{array}{l}\text { Ln tax administrative } \\
\text { burden }\end{array}$ & $\begin{array}{l}-0.093^{*} \\
\quad(-2.00)\end{array}$ & $\begin{array}{r}-0.096 * * \\
(-2.14)\end{array}$ & $\begin{array}{r}-0.099 * * \\
(-2.28)\end{array}$ & $\begin{array}{r}-0.104 * * \\
(-2.44)\end{array}$ & $\begin{array}{c}-0.133 * * * \\
(-2.83)\end{array}$ & - \\
\hline Ln corporate tax rate & - & $0.052(0.21)$ & $0.176(0.64)$ & $0.217(0.89)$ & $\begin{array}{l}0.094 \\
(0.37)\end{array}$ & $\begin{array}{l}-0.326 \\
\quad(-0.84)\end{array}$ \\
\hline Ln entry cost & - & - & $-0.043(-0.99)$ & $-0.057(-1.44)$ & $-0.055(-1.43)$ & $\begin{array}{l}-0.048 \\
\quad(-1.27)\end{array}$ \\
\hline $\begin{array}{l}\text { Ln average annual } \\
\text { wage }\end{array}$ & - & - & - & $-0.806(-1.15)$ & $-0.751(-1.31)$ & $\begin{array}{l}-0.692 \\
\quad(-1.08)\end{array}$ \\
\hline Growth & - & - & - & - & $0.019 * * *(3.34)$ & $\begin{array}{c}0.016 * * * \\
(2.86)\end{array}$ \\
\hline Constant & $1.812 * * *(343)$ & $1.614(1.70)$ & $1.192(1.16)$ & $9.516(1.31)$ & $9.379(1.62)$ & $10.38(1.63)$ \\
\hline$R^{2}$ & 0.03 & 0.03 & 0.04 & 0.06 & 0.12 & 0.07 \\
\hline No. of countries & 29 & 29 & 29 & 29 & 29 & 29 \\
\hline No. of observations & 159 & 159 & 159 & 158 & 158 & 159 \\
\hline
\end{tabular}

$t$ statistics based on robust standard errors in parentheses. Asterisks $(*),(* *)$ and $(* * *)$ denote statistical significance at the 10-, 5- and 1percentage levels, respectively. The maximum number of observations available for estimation is 161, but a few observations have been deleted because they are extreme outliers (|residual $\mid>3$ standard deviations) 
Table 10 Nascent entrepreneurship rate and tax administrative burden-panel regressions with fixed country effects, alternative specifications

\begin{tabular}{lllllll}
\hline & $(1)$ & $(2)$ & $(3)$ & $(4)$ & $(5)$ & $(6)$ \\
\hline Ln tax administrative burden & $0.013(0.25)$ & $0.018(0.32)$ & $0.014(0.27)$ & $0.014(0.26)$ & -0.023 & - \\
Ln corporate tax rate & - & & & $(-0.59)$ & $-0.054(-0.20)$ & $-0.116(-0.56)$ \\
Ln entry cost & - & $-0.065(-0.21)$ & $0.125(0.37)$ & $0.095(0.28)$ & $-0.074(-1.40)$ & $-0.074(-1.40)$ \\
Ln average annual wage & - & - & $-0.066(-1.25)$ & $-0.077(-1.48)$ & $-0.074(-0.80)$ & $-0.641(-0.79)$ \\
Growth & - & - & - & $-0.708(-0.81)$ & $-0.641(-0.024 *(2.62)$ & $0.023 * *(2.45)$ \\
Constant & $1.267 * * *(214)$ & $1.515(1.29)$ & $0.871(0.69)$ & $8.433(0.89)$ & $8.270(0.98)$ & $8.511(0.99)$ \\
$R^{2}$ & 0.00 & 0.00 & 0.01 & 0.02 & 0.08 & 0.08 \\
No. of countries & 29 & 29 & 29 & 29 & 160 & 29 \\
No. of observations & 160 & 160 & 160 & 160 & 29 \\
\hline
\end{tabular}

$t$ statistics based on robust standard errors in parentheses. Asterisks $(*),(* *)$ and $(* * *)$ denote statistical significance at the 10-, 5- and 1percentage levels, respectively. The maximum number of observations available for estimation is 161 , but a few observations have been deleted because they are extreme outliers ( $\mid$ residual $\mid>3$ standard deviations)

Table 11 New business ownership rate and tax administrative burden - panel regressions with fixed country effects, alternative specifications

(1)

$$
\begin{gathered}
-0.305^{* * * *} \\
(-2.88)
\end{gathered}
$$

$$
\text { burden }
$$

Ln corporate tax rate

$-$

Ln entry cost

Ln average annual wage

Growth

Constant

$R^{2}$

No. of countries

No. of observations$$
29
$$

158
(2)

$$
\begin{gathered}
-0.362 * * * \\
(-3.28)
\end{gathered}
$$$$
0.764 * *(2.15)
$$

(3)

$-0.364 * * *$
$(-3.31)$
$0.833 * *(2.16)$$$
-
$$$$
-0.024(-0.40)
$$$$
\text { - }
$$$$
-
$$$$
-
$$$$
-2.012(-1.47)
$$$$
0.20
$$$$
29
$$

(4)

$$
\begin{aligned}
& -0.366 * * * \\
& (-3.41) \\
& 0.793 * *(2.05) \\
& 9.809 \text { (1.32) }
\end{aligned}
$$

(5)

(6)

$$
\begin{array}{ll}
\begin{array}{l}
0.391 * * * \\
(-3.35)
\end{array} & - \\
0.691(1.68) & -0.451 \\
& (-0.55) \\
-0.040(-0.80) & \begin{array}{l}
c \\
0.025 \\
\end{array} \\
-1.087^{*}(-1.94) & -0.85) \\
& (-1.24) \\
0.016^{*}(1.72) & 0.008(0.81) \\
9.711(1.63) & 11.66 *(1.72) \\
0.24 & 0.02 \\
29 & 29 \\
157 & 159
\end{array}
$$$$
-1.130(-1.62) \quad-1.087 *(-1.94)-0.852
$$

$t$ statistics based on robust standard errors in parentheses. Asterisks $(*),(* *)$ and $(* * *)$ denote statistical significance at the 10-, 5- and 1percentage levels, respectively. The maximum number of observations available for estimation is 161 , but a few observations have been deleted because they are extreme outliers (|residual $\mid>3$ standard deviations) 
Table 12 Established business ownership rate and tax administrative burden - panel regressions with fixed country effects, alternative specifications

\begin{tabular}{|c|c|c|c|c|c|c|}
\hline & (1) & (2) & (3) & (4) & (5) & (6) \\
\hline $\begin{array}{l}\text { Ln tax administrative } \\
\text { burden }\end{array}$ & $\begin{array}{r}-0.152 * * \\
(-2.37)\end{array}$ & $\begin{array}{l}-0.137 * \\
(-1.85)\end{array}$ & $\begin{array}{l}-0.137 * \\
(-1.87)\end{array}$ & $\begin{array}{l}-0.139 * \\
(-1.91)\end{array}$ & $\begin{array}{l}-0.139 * \\
(-1.86)\end{array}$ & - \\
\hline Ln corporate tax rate & - & $-0.301(-1.19)$ & $-0.272(-1.09)$ & $-0.283(-1.07)$ & $-0.281(-1.06)$ & $\begin{array}{c}-0.658 * * * \\
(-3.14)\end{array}$ \\
\hline Ln entry cost & - & - & $-0.010(-0.32)$ & $0.008(0.28)$ & $0.008(0.27)$ & $0.014(0.45)$ \\
\hline Ln average annual wage & - & - & - & $-0.165(-0.43)$ & $-0.167(-0.43)$ & $-0.076(-0.17)$ \\
\hline Growth & - & - & - & - & $\begin{array}{c}-0.0003 \\
(-0.08)\end{array}$ & $-0.003(-0.74)$ \\
\hline Constant & $1.765 * * *(224)$ & $2.925 * * *(3.02)$ & $2.826 * * *(2.97)$ & $4.594(1.08)$ & $4.606(1.07)$ & $5.106(1.11)$ \\
\hline$R^{2}$ & 0.05 & 0.07 & 0.07 & 0.08 & 0.08 & 0.03 \\
\hline No. of countries & 29 & 29 & 29 & 29 & 29 & 29 \\
\hline No. of observations & 159 & 158 & 158 & 157 & 157 & 157 \\
\hline
\end{tabular}

$t$ statistics based on robust standard errors in parentheses. Asterisks $(*),(* *)$ and $(* * *)$ denote statistical significance at the 10-, 5- and 1percentage levels, respectively. The maximum number of observations available for estimation is 161 , but a few observations have been deleted because they are extreme outliers (|residual $\mid>3$ standard deviations)

Open Access This article is distributed under the terms of the Creative Commons Attribution 4.0 International License (http:// creativecommons.org/licenses/by/4.0/), which permits unrestricted use, distribution, and reproduction in any medium, provided you give appropriate credit to the original author(s) and the source, provide a link to the Creative Commons license, and indicate if changes were made.

\section{References}

Acs, Z. J., Desai, S., \& Klapper, L. F. (2008). What does 'entrepreneurship' data really show? A comparison of the Global Entrepreneurship Monitor and the World Bank Group datasets. World Bank Policy Research Working Paper no. 4667.

Aghion, P., Akcigit U., \& Howitt P. (2013). What do we learn from Schumpeterian growth theory? CESIS Working Paper no. 298, Centre of Excellence for Science and Innovation Studies, Royal Institute of Technology. KTH. Stockholm: CESIS.

Ardagna, S., \& Lusardi, A. (2009). Heterogeneity in the effect of regulation on entrepreneurship and entry size. NBER Working Paper no. 15510, Cambridge, MA.

Banerjee, A. V., \& Newman, A. F. (1993). Occupational choice and the process of development. Journal of Political Economy, 101(2), 274-298.

Belitski, M., Chowdhury, F., \& Desai, S. (2016). Taxes, corruption, and entry. Small Business Economics, 47(1), 201-216. https://doi.org/10.1007/s11187-016-9724-y.

Braunerhjelm, P., \& Eklund, J. E. (2014). Taxes, tax administrative burdens and new firm formation. Kyklos, 67(1), 1-11. https://doi.org/10.1111/kykl.12040.
Brock, W., \& Evans, D. (1986). The economics of small businesses: their role and regulation in the US Economy. New York: Holmes and Meier.

Chittenden, F., Kauser, S., \& Poutzioris, P. (2003). Tax regulation and small businesses in the US, UK, Australia and New Zealand. International Small Business Journal, 21(1), 93115. https://doi.org/10.1177/0266242603021001244.

Churchill, N. C., \& Lewis, V. L. (1983). The five stages of small business growth. Harvard Business Review, 61, 30-50.

Crain, W. M., \& Hopkins, T. D. (2001). The impact of regulatory costs on small firms: a report for the Office of Advocacy, U.S. Small Business Administration. RFP No. SBAHQ-00-R0027, Washington, D.C.

Cullen, J. B., \& Gordon, R. H. (2007). Taxes and entrepreneurial risk-taking: theory and evidence for the U.S. Journal of Public Economics, 91(7-8), 1479-1505. https://doi. org/10.1016/j.jpubeco.2006.12.001.

Da Rin, M., Di Giacomo, M., \& Sembenelli, A. (2011). Entrepreneurship, firm entry, and the taxation of corporate income: evidence from Europe. Journal of Public Economics, 95(9-10), 1048-1066. https://doi.org/10.1016/j. jpubeco.2010.06.010.

Djankov, S., Ganser, T., McLiesh, C., Ramalho, R., \& Shleifer, A. (2010). The effect of corporate taxes on investment and entrepreneurship. American Economic Journal: Macroeconomics, 2(3), 31-64. https://doi.org/10.1257 /mac.2.3.31.

Evans, D. S., \& Jovanovic, B. (1989). An estimated model of entrepreneurial choice under liquidity constraints. Journal of Political Economy, 97(4), 629-705.

GEM (2015). Global Entrepreneurship Monitor Data. www. gemconsortium.org.

Gentry, W. G., \& Hubbard, G. R. (2000). Tax policy and entrepreneurial entry. American Economic Review, 90(2), 283-287. https://doi.org/10.1257/aer.90.2.283. 
Gordon, R. H. (1998). Can high personal tax rates encourage entrepreneurial activity? IMF Staff Papers, 45(1), 49-80. https://doi.org/10.2307/3867329.

Hanks, S. H., Watson, C. J., \& Jansen, E. (1993). Tightening the life-cycle construct: a taxonomic study of growth stage configurations in high-technology organizations. Entrepreneurship Theory and Practice, 18(2), 5-29. https://doi.org/10.1177/104225879401800201.

Hanson, Å. (2008). Income taxes and the probability of becoming self-employed: the case of Sweden. Ratio Working Paper no. 122, Stockholm.

Henrekson, M., \& Sanandaji, T. (2011). Entrepreneurship and the theory of taxation. Small Business Economics, 37(2), 167185. https://doi.org/10.1007/s11187-009-9242-2.

Kauffman Foundation (2014). http://www.kauffman. org/newsroom/2014/06/small-business-owners-grade-theirstates-for-business-friendliness.

Koellinger, P. D., \& Thurik, R. A. (2012). Entrepreneurship and the business cycle. Review of Economics and Statistics, 94(4), 1143-1156. https://doi.org/10.1162/REST_a_00224.

Liang, J., Wang, H., \& Lazear, E. P. (2014). Demographics and entrepreneurship. NBER Working Paper no. 20506. Cambridge. Ma.

Lucas, R. E., Jr. (1978). On the size distribution of business firms. The Bell Journal of Economics, 9(2), 508-523. https://doi. org $/ 10.2307 / 3003596$.

Millán, J. M., \& Congregado, E. (2012). Determinants of selfemployment survival in Europe. Small Business Economics, 38(2), 231-258. https://doi.org/10.1007/s11187-010-9260-0.
Parker, S., \& Robson, M. (2004). Explaining international variations in self-employment: evidence from a panel of OECD countries. Southern Economic Journal, 71(2), 287-301. https://doi.org/10.2307/4135292.

Romer, P. M. (1990). Endogenous technological change. Journal of Political Economy, 98(5), 71-102.

Scott, B. R., \& Bruce, R. (1987). Five stages of growth in small business. Long Range Planning, 20(3), 45-52. https://doi. org/10.1016/0024-6301(87)90071-9.

Stam, E., \& Verbeeten, F. (2017). Tax compliance over the firm life course. International Small Business Journal, 35(1), 99-115. https://doi.org/10.1177/0266242615615185.

The Economist (2014). Red tape blues. Small businesses fret less about taxes than over-regulation. July 5 (http://www. economist.com/news/united-states/21606293-smallbusinesses-fret-less-about-taxes-over-regulation-red-tapeblues).

World Bank (2010). Entrepreneurship snapshots. http://siteresources.worldbank.org/INFOSHOP 1 /Resources/snapshots.pdf.

World Bank (2014a). Ease of doing business. www.worldbank. org.

World Bank. (2014). World development indicators. www. worldbank.org.

World Bank (2015). Sweden's business climate. A microeconomic assessment. Washington: World Bank.

Publisher's note Springer Nature remains neutral with regard to jurisdictional claims in published maps and institutional affiliations. 